\title{
Implementation of the Environmental
}

\section{Impact Statement}

Overemphasis on the preparation of the environmental impact statement (EIS) has resulted in inadequate implementation of the goals of the National Environmental Policy Act (NEPA). ${ }^{1}$ NEPA requires federal agencies to prepare EISs that assess and publicly record the environmental effects of alternative actions available to an agency. $^{2}$ By forcing agencies to gather and analyze information on the impact of proposed actions, Congress sought to enhance environmental quality. ${ }^{3}$ Agencies, however, have failed to use the EIS in designing subsequent actions and have neglected to establish procedures that ensure that the results of those actions conform to EIS predictions. As a result, the effectiveness of NEPA is in doubt.

This Note analyzes and criticizes two responses to this failure of the basic strategy of NEPA: the purely substantive response of requiring agencies to pick from the EIS the alternative action causing least harm to the environment, and the purely procedural response of the Council on Environmental Quality's (Council) new regulations, ${ }^{4}$ which merely require agencies to produce and disclose more infor-

1. Pub. L. No. 9l-190, 83 Stat. 852 (1969) (codified at 42 U.S.C. $\S \S 4321-4347$ (1970)). NEPA is divided into three major parts: $\$ \S 2,101,42$ U.S.C. $\$ \$ 4321,4331$ (setting out "Purpose" and "Declaration of National Environmental Policy"); $\$ \$ 102-105,42$ U.S.C. $\$ \$ 4332-4335$ (establishing procedures to facilitate achievement of national policy); $\$ \S 201$ 207, 42 U.S.C. $\$ \$ 4341-4347$ (establishing Council on Environmental Quality to advise President and coordinate environmental policy in executive branch).

2. Section $102(2)(C), 42$ U.S.C. $\$ 4332(2)(C)(1970)$, requires all federal agencies to "include in every recommendation or report on proposals for legislation and other major federal actions significantly affecting the quality of the human environment, a detailed statement [EIS] by the responsible official."

3. See Vermont Yankee Nuclear Power Corp. v. Natural Resources Defense Council, Inc., 435 U.S. 519, 558 (1978) (message of NEPA both procedural and substantive); S. REP. No. 296, 91st Cong., 1st Sess. 19-20 (1969) (EIS designed to implement NEPA goal of environmental quality); R. Liroff, A National Policy for the Environment 74-82 (1976) (NEPA's primary purpose is to change agency behavior by requiring agency consideration of more and different information, although tendencies in organizational behavior make agencies consider only information supportive of their missions); Andrews, Agency Responses to NEPA: A Comparison and Implications, 16 NAT. Resources J. 301,322 (1976) ("The enactment of NEPA was an attempt to bring about administrative changc by changes in procedures . . . ."); Dreyfus \& Ingram, The National Environmental Policy Act: A View of Intent and Praclice, 16 Nat. Resources J. 243, 254 (1976) ("Above all, the impact statement was not intended merely to provide data or description, but to force a change in the administrative decisions affecting the environment.")

4. 43 Fed. Reg. 25,230 (1978) (to be codified at 40 C.F.R. $\$ 1500$ ) [hereinafter cited by section as Proposed Regulations]. An earlier draft of the Regulations was circulated among agencies and made available to the public. 8 ENVIR. REP. (BNA) 1236, 1291 (1977). 
mation. The Note concludes that the substantive response is not feasible, and that the procedural response is not adequate. Alternatively, the Note proposes a middle ground that gives agencies discretion in the choice of action, but requires that all practicable measures be employed to mitigate environmental harm caused by the actions chosen.

\section{The Failure to Achieve NEPA's Goals Through the Preparation of EISs}

Operating at the behest of private litigants, courts have carried the major responsibility for enforcing the requirement that agencies prepare EISs for all actions that significantly affect the environment. ${ }^{5}$ The Council, through its Guidelines, ${ }^{6}$ has defined for courts ${ }^{7}$ and agencies $^{8}$ the subjects that must be discussed in the EIS. ${ }^{9}$

Both the Council and the courts have emphasized the requirement that agencies include relevant information in the EIS, but have not fo-

5. Of the 654 cases filed under NEPA from 1970 to 1975,363 challenged agency action because no EIS had been prepared, and most of the remaining 291 cases challenged the adequacy of the EIS. Council on Evironmental Quality, ENvironmental IMPact StateMENTs 31, 32 (1976) [hereinafter cited as Couscil STuby]; see, e.g., Greene County Planning Bd. v. FPC, 455 F.2d 412 (2d Cir.), cert. denied, 409 U.S. 849 (1972) (Federal Power Commission must prepare EIS); Calvert Cliffs' Coordinating Comm. v. Atomic Energy Comm'n, 449 F.2d 1109 (D.C. Cir. 1971) (Atomic Energy Commission must prepare EIS). See generally F. ANDERSON, NEPA in THE CourTs (1973) (review of cases requiring preparation of EIS); Cortner, $A$ Case Analysis of Policy Implementation: The National Environmental Policy Act of 1969, 16 Nat. Resources J. 323, 329-34 (1976) (importance of courts in ensuring preparation of EIS).

6. The Council has maintained two roles throughout its eight years of existence: (1) advisor to the President on general environmental matters, and (2) supervisor of NEPA's implementation by the executive branch. See R. ANdrews, ENvironimental Policy AND Administrative Change 27-41 (1976); R. Liroff, supra note 3, at 36.73. Pursuant to the latter duty, the Council has issued Guidelines for the preparation of the EIS, 40 C.F.R. $\$ 1500$ (1977). The proposed regulations, issued under the authority of Exec. Order No. I1,991, 42 Fed. Reg. 26,967 (1977), will update these procedures.

7. See W. Rodgers, ENvironsiental LAw 705 (1977) (“[T] have settled upon a course of deference to ... [Council] guidance and interpretations of NEPA.")

8. Id. at 706 (most federal agencies have promulgated regulations that follow Council Guidelines).

9. The EIS must include descriptions of: (1) the existing environment to be affected by agency action, 40 C.F.R. $\$ 1500.8$ (a)(1) (1977); (2) the proposed action and its purposes, $i d . ;$ and (3) the relationship of the action to land use plans and controls in the affected area, id. $\$ 1500.8(\mathrm{a})(2)$. It must suggest general "alternative" means of performing the action, id. $\$ 1500.8(a)(4)$, and "mitigation methods" for minimizing the adverse consequences of each alternative, $i d . \$ 1500.8(a)(5)$. Finally, the EIS must predict the impact of the agency action on the environment, $i d$. $\$ 1500.8(a)(3)$, including unavoidable adverse consequences, $i d$. $\$ 1500.8(a)(5)$, the relationship of the short-term use under agency plans to long-term productivity, $i d$. $\$ 1500.8(a)(6)$, and resulting irretrievable commitments of resources, id. $\$ 1500.8(a)(7)$. 
cused on the use made of the EIS in implementing the agency action. ${ }^{10}$ Courts, the Council, and commentators have inferred two major functions of the EIS from the structure of NEPA: forcing the agency to expand the universe of information available to it through the process of EIS preparation, ${ }^{11}$ and notifying other federal agencies, state and local governments, citizens, and Congress of the nature of the proposed agency action and its potential impact on the environment. ${ }^{12}$ These functions, however, are valuable only insofar as they help to minimize environmental harm caused by agency actions and thereby to achieve the purpose of NEPA. ${ }^{13}$

NEPA attempts to remedy the tendency of federal agencies to ignore the adverse environmental consequences of their decisions because of the single-mindedness with which they pursue their "missions." 1 it

10. The NEPA case law has been dominated by the requirement that agencies prepare the EIS and include relevant information in it. See, e.g., County of Suffolk v. Secretary of Interior, 562 F.2d 1368 (2d Cir. 1977), cert. denied, 434 U.S. 1064 (1978) (information required in EIS for offshore oil leasing); City of Davis v. Coleman, 521 F.2d 661 (9th Cir. 1975) (information required in EIS for freeway interchange); Calvert Cliffs' Coordinating Comm. v. Atomic Energy Comm'n, 449 F.2d 1109 (D.C. Cir. 1971) (EIS must be prepared prior to agency decision); Council Study, supra note 5, at 31-32. The Council Guidelines specify who shall prepare the EIS, 40 C.F.R. $\$ 1500.4$ (1977), when they shall be prepared, id. $\$ 1500.2(a)$, and what they shall contain, $i d$. $\$ 1500.8$, but they do not say what must be done with the EIS after it is prepared and circulated to other agencies for comment, id. $\$ 1500.9$. "[T] tion and an order to shore up the statement." Natural Resources Defense Council, Inc. v. Callaway, 389 F. Supp. 1263, 1277 (D. Conn. 1974), rev'd on other grounds, 524 F.2d 79 (2d Cir. 1975).

11. See, e.g., Sierra Club v. Morton, 510 F.2d 813, 819 (5th Cir. 1975) (EIS to provide information to agency prior to oil and gas leasing); Trout Unlimited v. Morton, 509 F.2d 1276 (9th Cir. 1974) (EIS to provide information on Teton dam project); D'Amato \&. Baxter, The Impact of Impact Statements Upon Agency Responsibility: A Prescriptive Analysis, 59 IowA L. REv. 195 (1973) (setting out NEPA's goals).

12. See Environmental Defense Fund, Inc. v. Corps of Eng'rs, 325 F. Supp. 749, 759 (E.D. Ark. 1971), modified, 342 F. Supp. 1211, aff'd, 470 F.2d 289 (8th Cir. 1972), cert. denied, 412 U.S. 931 (1973) ("At the very least, NEPA is an environmental full disclosure law . . . . The 'detailed statement' required by $\S 102(2)(C)$ should, at a minimum, contain such information as will alert the President, the Council ...., the public, and indeed, the Congress, to all known possible environmental consequences of proposed agency action.") (emphasis in original). Disclosure to both the public and agencies has been used largely to trigger suits or comments identifying inadequacies in the EIS. CounciL STUdY, supra note 5 , at 31.32 (predominance of suits challenging agency decision not to prepare EIS or challenging adequacy of EIS). Disclosures in the EIS, however, have not prevented agency action with adverse environmental effects. Neither Congress nor the Office of Management and Budget, the two institutions with direct control over agencies through the budget, has moved to stop such actions. R. Liroff, supra note 3, at 122-24, 139. Indeed, Congress removed the requirement of further preparation of an EIS in the celebrated case of the Trans-Alaska Pipeline System. Trans-Alaska Pipeline Authorization Act, Pub. L. No. 93-153, 87 Stat. 584 (1973) (codified in 43 U.S.C. $\$ \S 1651-1655$ (Supp. V 1975)).

13. See note 3 supra (purpose of NEPA).

14. R. LiRoFf, supra note 3 , at 75-82.

The mission of an agency is defined by the goals that its members wish to achievc (e.g., construction of dams by the Corps of Engineers or elimination of pollutants by the 
NEPA does not seek to change the existing missions of government agencies; rather it seeks to add the goal of improved environmental quality. ${ }^{15}$ The assumption that environmental quality could be enhanced simply by increasing information and agency disclosure, however, has proved fallacious. ${ }^{16}$ Change in the type and amount of information available, without a corresponding change in the manner in which it is evaluated and used, simply has not had significant influence on agency actions. ${ }^{17}$

Because agency attention has focused exclusively on preparation of the EIS, procedures for employing it have been ignored. No duty to use the EIS has been imposed, ${ }^{18}$ and there is no way to judge the

Environmental Protection Agency). These goals result from the common training, experiences, and social environment of the agency members and the agency's external sources of support. See A. Downs, Inside. Bureaucracy 43-87 (1967) (discussion of motivation of officials within organizations); H. Simon, D. SMrthburg \& V. Thompson, Public ADMinistration 55-102 (1950) (organization's mission determined by internal goals and external controls); A. Wildavsky, The Politics of the Budgetary Process (2d ed. 1974) (external control of agencies through budgetary process). Underlying these goals is the desire of the agency's members to continue the agency's existence and increase its budget and power. See Niskanen, Bureaucrats and Politicians, 18 J.L. \& EcoN. 617, 618 (1975) (noting theory that mission of organizations is to maximize own budget).

15. R. ANDREws, supra note 6 , at 153 (" $[1] \mathrm{f}$ environmental information could be placed before each official in the decision process along with the traditional information about proposed actions and their alternatives, it would influence the decision in the direction of NEPA's policy goals.")

16. See Andrews, supra note 3, at 320 (achievement of NEPA's policies not caused by implementation of its procedures); Bardach \& Pugliaresi, The Environmental Impact Statement v. The Real World, Pub. INTERest, Fall 1977, at 22, 24 (EIS merely procedural tool); Cortner, supra note 5, at 336 ("While substantive change may occur as the result of formal compliance with procedures, new procedures and rules do not necessarily change attitudes or behavior if basic agency decisions can remain the same."); Fairfax, $A$ Disaster in the Environmental Movement, 199 Scr. 743 (1978) (NEPA has diverted attention from substantive change); Sax, The (Unhappy) Truth About NEPA, 26 OkLA. L. REv. 239 (1973) (procedural changes alone are inadequate). But see Wichclman, Administrative Agency Implementation of the National Environmental Policy Act of 1969: A Conceptual Framework for Explaining Differential Response, 16 Nat. ResourCes J. 263, 279 (1976) (substantive change from NEPA's procedural innovation is occurring gradually); cf. Council Study, supra note 5, at 23, D-1 to D.4 (examples of changes in agency decisions resulting from EIS preparation).

A major difficulty in evaluating the success of NEPA has been the impossibility of determining whether the EIS, once prepared, influences decisions. See Council STUDY, supra note 5, at 21 "'In sceking information on this subject [influence of NEPA on agency decisions] from agencies, states, and other sources, the Council encountered mostly gray areas.")

17. See note 16 supra. The modest substantive changes resulting from NEPA can be attributed largely to other factors. See R. ANDREws, supra note 6, at 157, 158 (delay from lawsuits and controversy as reasons for change); $R$. LiroFF, supra note 3 , at 130-32 (change in personnel); Wichelman, supra note 16, at 280.84 (establishment of independent cnvironmental offices within agencies). Agencies with primary missions favorable to the environment seem to make greater use of the EIS. See CounclL STUdy, supra note 5, at D.3 to D.4 (Forest Service uses EIS as basic planning document for forest lands).

18. It is arguable that NEPA created no substantive duties, but only procedures that would allow political pressure to change agency decisions. This view, however, ignores Congress's intent that the procedures be used as means to achieve substantive policy 
extent to which an agency actually uses information generated in the EIS preparation process in designing its action. ${ }^{19}$ There is, moreover, no explicit requirement that agencies employ the "mitigation measures"20 that must be suggested in the EIS $^{21}$ and there is no standard for determining which suggested measures ought to be used.

Disregard for use of the EIS in implementation has contributed to its inadequacies as a scientific device. ${ }^{22}$ The EIS fundamentally should be a scientific document that collects data from a variety of sources and predicts the results of introducing new factors into an environmental system. Minimally, the scientific method requires observation, verification and criticism of hypotheses, and subsequent use of the confirmed or altered hypotheses. ${ }^{23}$ Continuous monitoring over a long period is especially important in environmental analysis because of the numerous variables, interrelationships, and unexpected effects that accompany newly introduced factors. ${ }^{24}$

None of these monitoring activities are presently required after preparation of an EIS. Observation and monitoring rarely occur, ${ }^{25}$

ends. See note 3 supra. The EIS was meant to be a decision document that would affect the policymaking process. R. LiRoFf, supra note 3, at 17 (draftsmen of NEPA relied on "decision documents" as models for EIS). Congress delegated to the executive branch, especially the Council and the agencies, the task of determining the mechanics of using the EIS in decisionmaking. The Council Guidelines and proposed regulations have evolved to fulfill that task under the direction of executive orders. See note 6 supra.

19. See note 16 supra.

20. See pp. $601,607.08$ infra.

21. See Council on Environmental Quality, NFPA Hearing Questionnaire 35 (July 1977) (on file with Yale Law Journal) ("Considerable testimony asserted that the EIS process where working well results in mitigation measures to minimize the harmful environmental impact of the process. There was some skepticism as to whether the mitigation is in fact always carried out.") Mitigation measures can be used in a variety of circumstances. See Life of the Land v. Brinegar, 485 F.2d 460, 473 (9th Cir. 1973) (new habitat for endangered bird species developed concurrently with runway extension); Bucks County Bd. of Comm'rs v. Interstate Energy Co., 403 F. Supp. 805, 814 n.15 (E.D. Pa. 1975) (change in route of pipeline and location of pumping stations to minimize environ. mental harm); Simmans v. Grant, 370 F. Supp. 5, 11 (S.D. Tex. 1974) (change in route of dredged channel); $c f$. Watson, Measuring and Mitigating Socio-Economic Environmental Impacts of Constructing Energy Projects: An Emerging Regulatory Issue, 10 NAT. RESOURCES LAw. 397 (1977) (importance of mitigation of impact on public services when major energy facility is located in undeveloped area).

22. See Carpenter, The Scientific Basis of NEPA-Is it Adequate? 6 ENvT'L L. Rep. 50,014 (1976) (inadequacies of EIS as scientific device); Fairfax, supra note 16 (EIS has major scientific defects); Schindler, The Impact Statement Boondoggle, 192 Sc1. 509 (1976) (EIS wanting as scientific tool).

23. See Fairfax, supra note 16 , at 745 (proper scientific inquiry must proceed gradually, under full scrutiny of skeptical and disciplined profession).

24. See Carpenter, supra note 22, at 50,017-18 (development of good ecological information requires constant and lengthy observation); cf. Gelpe \& Tarlock, The Uses of Scientific Information in Environmental Decisionmaking, 48 S. CAL. L. REv. 371, 389-412 (1974) (describing complexity of ecosystems).

25. See Council Srudy, supra note 5, at 54; Carpenter, supra note 22, at 50,017, 50,019. 
and the EIS thus is not subject to scientific criticism. ${ }^{26}$ Because of the impossibility of observation and criticism, predictions of the environmental impact of actions and of the relative merits of various mitigation measures included in an EIS cannot be analyzed. The EIS, therefore, is of minimal scientific value as a guide to agency action.

\section{Two Responses to Failures of the Current System}

\section{A. Judicial Imposition of a Duty to Choose the Least Adverse Alternative}

Some critics have urged that courts require agencies to choose on the basis of the EIS, from among available options, the alternative course of action that promises the least harm to the environment. This substantive response, however, is unworkable because it would override the decision of an agency that reflects its sense of mission most strongly. Such "primary" decisions between policy alternatives should be distinguished from "secondary" choices of measures to implement the primary decision. ${ }^{27}$

Forcing an agency to adopt the least adverse alternative often could require that agency to choose to take no action or to recommend action by another agency. ${ }^{28}$ Such choices would be contrary to the

26. See Schindler, supra note 22, at 509 (EISs "have formed a 'gray literature' so diffuse, so voluminous, and so limited in distribution that its conclusions and recommendations are never scrutinized by the scientific community at large").

27. See pp. 607-08 infra; Council Guidelines, 40 C.F.R. $\$ \S 1500.8(a)(4)-(5)$ (1977); D'Amato \& Baxter, supra note 11, at 208-22, 233-34.

Commentators arguing for judicial review of the substance of the agency decision concentrate on the primary decision. See, e.g., Leed, The National Environmental Policy Act of 1969: Is the Fact of Compliance a Procedural or Substantive Question? I5 SANTA ClARA LAw. 303 (1975); Wharton, Judicially Enforcable Substantive Rights Under NEPA, 10 U.S.F. L. REv. 415 (1976); Note, The Least Adverse Alternative Approach to Substantive Review Under NEPA, 88 HARv. L. REv. 735 (1975).

28. In its EIS an agency must consider the possibility of "no action," Council Guidelines, 40 C.F.R. $\$ 1500.8$ (a)(4) (1977); see Environmental Defense Fund, Inc. v. Corps of Eng'rs, 325 F. Supp. 749, 761 (E.D. Ark. 1971), modified, 342 F. Supp. 1211, aff'd, 470 F.2d 289 (8th Cir. 1972), cert. denied, 412 U.S. 931 (1973), and the possibility of alternatives outside its jurisdiction, Natural Resources Defense Council, Inc. v. Morton, 458 F.2d 827, 834, 835 (D.C. Cir. 1972) (Department of Interior must consider variety of alternatives to of shore oil and gas leasing in Gulf of Mexico, including ending oil import quotas, increasing nuclear development, and changing FPC natural gas pricing). When considering alternatives, an agency may be forced to look at choices that diminish its reason for existence. Consideration of such primary alternatives contrasts with the decision to select mitigation measures, which requires an agency to adjust rather than abandon its preferred course of action. Organization theory suggests that an agency's major goal is maximizing its budget, see Niskanen, supra note 14 , at 618 , and thus explains the disparity in the relative threats to an agency's mission when it selects an alternative and chooses a mitigation measure. If an agency must choose the alternative of no action or an action within the jurisdiction of another agency, the agency's budget will be reduced. On the 
agency's sense of mission, since they would decrease the agency's budget and power. ${ }^{29}$ Any attempt to require such choices, therefore, would be bound to encounter severe agency resistance. ${ }^{30}$

A judicial requirement that an agency adopt the least damaging alternative $^{31}$ is also unlikely because NEPA does not provide standards to guide courts in requiring such agency action. Many courts have accepted the principle that NEPA sets substantive goals for agencies, ${ }^{32}$ but no court has found that an agency's selection of a particular alternative violated those goals. ${ }^{33}$ The absence of substantive judicial review is understandable, because NEPA does not define the weight that is to be given to environmental values in relation to other national policy goals pursued by an agency. ${ }^{3 *}$ With the exception of cases of blatant bad faith by an agency, therefore, courts are unable to scrutinize a particular agency policy choice.

\section{B. The New Council Regulations}

Under the authority of an executive order, ${ }^{35}$ the Council has recently proposed new regulations governing preparation of the EIS.36

other hand, the choice of a particular mitigation measure may result in a larger budget and more authority, because an agency's budget often is determined project-by-project. See R. ANDREws, supra note 6, at 48 (authorization for individual projects rather than for total agency budget).

29. The substantive response would be a first-best solution only if the agency's sense of mission would not be affected adversely, and if environmental values always outweighed "other essential considerations of national policy," NEPA, $\S 101(\mathrm{~b}), 42$ U.S.C. $\$ 4331$ (b) (1970). Since neither of these conditions are realistic, however, the second-best solution of structuring agency choice of mitigation measures is desirable.

30. Such agency resistance occurred when the Council attempted to limit the factors upon which an agency could rely in selecting any alternative other than the least environmentally damaging one. Agencies strongly objected to their inability to consider other factors that might be supportive of their missions. 8 ENVIR. REP. (BNA) 902 (1977); see $\mathrm{R}$. ANDrews, supra note 6 , at 157,158 (agencies less resistant to changing design than basic action).

31. See Note, supra note 27 (arguing for such judicial enforcement).

32. See, e.g., Sierra Club v. Froehlke, 486 F.2d 946 (7th Cir. 1973) (NEPA sets substantive goals); Environmental Defense Fund, Inc. v. Corps of Eng'rs, 470 F.2d 289 (8th Cir. 1972), cert. denied, 412 U.S. 931 (1973) (possibility of substantive review); W. RodGers, supra note 7, at 741 n.23 (citing cases). Contra, Lathan v. Brinegar, 506 F.2d 677 (9th Cir. 1974) (NEPA characterized as purely procedural statute).

33. Council Study, supra note 5 , at 32 .

34. See 42 U.S.C. $\$ 4331(\mathrm{~b})$ (1970) (agencies are "to use all practicable means" to carry out policy of NEPA, but they must do so "consistent with other essential considerations of national policy"); $R$. LiRofF, supra note 3, at 76, 84 (NEPA does not choose among possible national policies). The Council Guidelines limit themselves to the procedural aspects of NEPA. See 40 C.F.R. $\$ 1500$ (1977).

35. Exec. Order No. 11,991, 42 Fed. Reg. 26,967 (1977).

36. The existing Council Guidelines are found at 40 C.F.R. $\$ 1500$ (1977). The new Regulations have three basic purposes: reducing paperwork, minimizing delays, and securing decisions that better reflect the EIS. Proposed Regulations, supra note $4, \$ 1500.1$. All federal agencies are to develop regulations that conform to the new regulations 


\section{Environmental Impact Statement}

The new regulations demonstrate concern with agency use of the EIS after its preparation, ${ }^{37}$ but generally follow the familiar strategy of modifying agency behavior through disclosure requirements alone. First, the new regulations require an agency to produce a "public record of decision" stating how it used the EIS in its decisionmaking and what, if any, mitigation measures it adopted. ${ }^{38}$ Second, the proposed regulations provide that after adopting mitigation measures, an agency has a duty to implement and enforce them. ${ }^{39}$ Finally, an agency may establish a program to monitor all implemented mitigation measures and publicize their results. ${ }^{40}$

The initial requirement, that an agency produce a record of decision, ensures that the agency will at least inform the public of how it uses the EIS. Moreover, the requirement facilitates subsequent evaluation of an agency's use of the EIS. ${ }^{41}$ Absent a substantive standard of agency decisionmaking, however, disclosure of the agency selection cannot guarantee that the selection will minimize harm to the environment. Indeed, the history of NEPA suggests that neither an increase of information prior to a decision nor disclosure of reasons after a decision will, without more, affect agency decisionmaking. ${ }^{42}$

The requirement that an agency implement or enforce mitigation measures focuses on a decision that is less central to the agency's mission than its choice of a primary alternative. The requirement, therefore, is more likely to be effective ${ }^{43}$ than the mandate that an agency select policies that themselves minimize environmental harm. Yet, the proposed implementation requirement relies solely on disclosure to influence the selection of mitigation measures; the record of decision need only contain a statement of "[w] hether all practicable means

within eight months of the final rulemaking. Id. $\S 1507.3$. These agency regulations must integrate the new requirements into the basic structure of each agency's policymaking process. Id. $\$ 1505.1(\mathrm{~b})$.

37. See 43 Fed. Reg. 25,231 (1978) ("Most of the features described above will help to improve decisionmaking. This, of course, is the fundamental purpose of the NEPA process, the end to which the EIS is a means .... A central purpose of these regulations is to tie means to ends.")

38. Proposed Regulations, supra note 4, $\$ 1505.2$. This record "may be integrated into any other record prepared by the agency," $i d$., but some record must be prepared. The record must include the decision, a statement of national policy reasons that necessitated selection of an alternative other than the least damaging one, and a statement of "[w]hether all practicable means to aroid or minimize environmental harm have been adopted, and if not, why they were not." Id. $\$ 1505.2(\mathrm{c})$.

39. Id. $\$ 1505.3$. The agency must implement mitigation measures in actions directly under its control and enforce them when a private developer or subordinate governmental unit is directly responsible for the action. Id.

40. Id.

41. See R. LiRoff, supra note 3, at 84,85 (noting lack of device for measuring use).

42. See note 16 supra (citing sources).

43. See notes 29-30 supra. 
to avoid or minimize environmental harm have been adopted," and if not, why not. ${ }^{44} \mathrm{~A}$ statement listing the mitigation measures that an agency has selected will be ineffective unless governed by a standard that indicates which measures ought to have been selected.45

Finally, the requirement that an agency establish monitoring programs reflects an awareness of two problems: the failure of agencies to implement mitigation measures they have chosen and the inadequacy of the EIS as a scientific device. The new requirement clearly responds to the failure of agencies to implement or enforce mitigation measures; agencies must at least establish programs of inspection to ensure that adopted mitigation measures are implemented. However, the new regulations leave unclear whether the monitoring program merely involves supervision of the application of mitigation measures, or whether it should instead include scientific observation of the effectiveness of the measures. ${ }^{46}$

Scientific observation is crucial to effective utilization of the EIS. In some situations an agency will be unable to obtain all information that is relevant to its EIS before the primary decision is made, but will be able to secure that information later if it adopts a monitoring program that includes scientific observation. ${ }^{47}$

If information based on subsequent scientific observation were reflected in a revised EIS, the agency would be more likely to make informed decisions in the future. ${ }^{48}$ Publication of data gathered from

44. Proposed Regulations, supra note 4, $\$ 1505.2(\mathrm{c})$. Such a statement undoubtedly will provide information so that an EIS can be more successfully scrutinized and the agency can have the benefit of more thoughtful criticism. The utility of even this information function, however, is undercut by the absence of a standard that indicates when particular mitigation measures are appropriate.

45. The proposed regulations are unable to provide standards to govern the creation and implementation of mitigation measures precisely because they fail to differentiate adequately and consistently between mitigation measures and primary alternatives. Although the proposed regulations distinguish the two in the record of decision, they are merged both in the definitions of alternatives, $i d$. $\$ 1502.14$, and mitigation measures, id. $\S 1508.19$. This conflation reveals a lack of appreciation for the intensity of the agency sense of mission that is present when an agency is choosing among primary alternatives, as opposed to mitigation measures. When agencies resisted the imposition of a duty to select the least adverse alternative, see note 30 supra, the draftsmen did not adopt the second-best approach of requiring adoption and implementation of mitigation measures pursuant to a substantive standard.

46. "Monitoring" is not defined in the proposed regulations.

47. The classic example of this situation is outer continental shelf oil and gas development. See D. Kash, Energy Under the Oceans 26-62 (1973). At the outset of exploration, little is known about the location or quantity of commercially exploitable oil and gas in relation to marine resources. As exploratory surveys, drilling, and finally production occur, further information is developed. Id.; see County of Suffolk v. Secretary of Interior, 562 F.2d 1368 (2d Cir. 1977), cert. denied, 434 U.S. 1064 (1978) (problems of delay and confusion that can arise in outer continental shelf oil and gas development when decisions are made on basis of EIS with inevitably incomplete information).

48. See Carpenter, supra note 22, at 50,017, 50,019. 
such monitoring programs could give observers information on which to base evaluation of future projects. Moreover, publication would expose the EIS to the scrutiny of the scientific community. The value of publication, therefore, depends on the structure of monitoring programs; mere publication of the fact of implementation of mitigation measures will have minimal scientific value.

\section{Recommended Amendments to the Proposed Regulations}

Each of the two major responses to NEPA's failures offers important advantages; yet each also has significant deficiencies. The least-adversealternative approach promises a more ambitious role for the EIS, but would require an unworkable standard. The Council's proposed regulations provide a valuable public record and recognize the importance of monitoring, but they continue to rely on disclosure mechanisms to achieve substantial policy goals. A synthesis of the two responses would impose on agencies a standard for implementation of mitigation measures.

\section{A. Recommended Amendments to the Council's Proposed Regulations}

Agencies must be bound by a standard that governs adoption of mitigation measures in order to increase the likelihood that an agency will minimize environmental harm in implementing a primary policy decision. The standard must be sufficiently flexible to deal with the variety of situations that arise under NEPA. ${ }^{49}$ Moreover, in order to minimize agency resistance to promoting environmental quality, the standard must not interfere with an agency's choice of primary policy goals. ${ }^{50}$ The standard must guide agencies in the preparation and implementation of the EIS, and must permit observers to scrutinize agency compliance carefully. Such a standard can be implemented by adoption of the following amendment to the proposed Council regulations:

Agencies shall:

(a) adopt all practicable mitigation measures available for the alternative chosen and identified as practicable in the EIS;

49. See, e.g., Kleppe v. Sierra Club, 427 U.S. 390 (1976) (regional plan or program for development of Northern Great Plains coal resources); City of Davis v. Coleman, 521 F.2d 661 (9th Cir. 1975) (freeway interchange); Environmental Defense Fund, Inc. v. Froehlke, 473 F.2d 346 (8th Cir. 1972) (dam and channelization project).

50. See pp. 601-02 supra (discussing agency resistance to interference with choices among policy goals). 
(b) produce a public record of decision that shows the alternative chosen and the mitigation measures adopted, and that explains why mitigation measures identified in the EIS but not adopted are impracticable;

(c) implement or enforce all mitigation measures adopted, either through the plans, designs, recommendations, and actions of the agency or through conditions on grants and licenses given to other parties;

(d) supervise implementation of the mitigation measures to ensure their use and establish a monitoring program to observe and verify the effects of mitigation measures predicted in the EIS;

(e) publicize the results of monitoring programs with comparisons of the predicted and observed effects of the mitigation measures implemented, and use those results in future, similar EISs. ${ }^{.1}$

Central to such an amendment is the practicability standard. This standard corresponds to the language of $\mathrm{NEPA}^{52}$ and the proposed regulations themselves. ${ }^{53}$ Moreover, the meaning of the term "practicable" is illuminated by its use in similar contexts in which an action is adjusted to minimize some danger without preventing achievement of the primary policy goal. ${ }^{5 t}$

Three factors typically are taken into account in defining practicability: the state of the technological art, the cost of the measure, and the amount of harm avoided. If a mitigation measure is beyond the current state of the technological $\operatorname{art}^{55}$ or if it is prohibitively ex-

51. This amendment would replace Proposed Regulations, supra note 4, $\$ \S 1505.2-3$.

52. See NEPA, $\$ 101$ (b), 42 U.S.C. $\$ 4331$ (b) (1970) ("In order to carry out the policy set forth in [this Act], it is the continuing responsibility of the Federal Government to use all practicable means, consistent with other essential considerations of national policy, to improve [its plans to cause less harm to the environment] . . . ") (emphasis added).

53. The proposed regulations already require a statement of "[w] means to avoid or minimize environmental harm have been adopted." Proposed Regulations, supra note $4, \S 1505.2$ (c) (emphasis added).

54. The Federal Water Pollution Control Act Amendments of 1972, 33 U.S.C. $\$ \S 1251$ 1376 (Supp. V 1975) [hereinafter cited as Water Pollution Control Act], require use of "the best practicable control technology currently available" to avoid water pollution while allowing industrial or municipal activity to continue. Id. $\$ 1311(\mathrm{~b})(\mathrm{l})$ (emphasis added). The National Traffic and Motor Vehicle Safety Act requires establishment of "practicable" safety standards to avoid harm to users of automobiles, but allows automobile manufacture and use to continue. 15 U.S.C. $\$ \$ 1392(a)$, (f) (1970). Remedies commonly available in nuisance law include use of practicable methods to avoid harm to public or private environments. See W. RoDGERs, stupra note 7, at 143 .

55. See, e.g., Chrysler Corp. v. Department of Transp., 472 F.2d 659, 673-74 (6th Cir. 1972) (under National Traffic and Motor Vehicle Safety Act state of art of passive rcstraints shows they are practicable); Folmar v. Elliot Coal Mining Co., $441 \mathrm{~Pa}$. 592, 272 A.2d 910 (1971) (no damages awarded in nuisance case because control was not technologically feasible); Watcr Pollution Control Act, 33 U.S.C. $\$ 1311(b)(1)$ (Supp. V 1975) (practicable control technology must be currently available). 
pensive, ${ }^{56}$ it is not practicable. In all instances, there must of course be an actual harm that is avoided.

When applying the practicability standard, it is important to differentiate clearly between an agency's discretionary selection of alternative courses of action and the nondiscretionary choice of mitigation measures. This can be accomplished by Council adoption of the following definitions:

(a) The chcice of alternatives requires consideration of the goals the agency wishes to achieve and the major outlines of the agency action. The choice includes:

(1) whether to take no action or some action; and

(2) whether to take an action within the agency's jurisdiction or to recommend that another agency or institution be responsible for achieving the desired results. ${ }^{57}$

(b) Mitigation measures include:

(1) changing the design or details of an alternative to minimize environmental harm;

56. See, e.g., CPC Int'l, Inc. v. Train, 540 F.2d 1329, 1341-43 (8th Cir. 1977) (in Water Pollution Control Act litigation, cost helps define practicability); Renken v. Harvey Aluminum, Inc., 226 F. Supp. 169, 174 (D. Or. 1963) (nuisance law requires remedy unless defendant can show it is prohibitively expensive).

A mitigation measure would be unjustifiably expensive if its cost outweighed its benefits. Admittedly, the art of cost-benefit analysis is imprecise. See generally Rosen, CostBenefit Analysis, Judicial Review, and the National Environmental Policy Act, 7 ENvr'L L. 363 (1977). Common problems include establishment of an appropriate discount rate for future benefits and costs, valuation of nonhuman lives and ecological diversity, and measurement of the cost and risk of possible future catastrophes. See B. ACKERMAN, S. Rose-Ackerman, J. Sawyer \& D. Henderson, The Uncertain Search for Environmental. Quality 104.46 (1974) (review of such problems); Yellin, Judicial Review and Nuclear Power, 45 GEO. WASH. L. REv. 969 (1977) (difficulties of assessing cost of unlikely, but disastrous event).

An agency, however, often will be able to measure benefits or costs by the decreased or increased distance users of one resource will have to travel to enjoy a similar resource, or by the costs of producing a similar resource in a different locale if no comparable resource is available. See B. Ackerman, S. Rose-Ackerman, J. Sawyer \& D. Henderson, supra, at 104-19 (making such measurements). In other situations an agency will not have to perform a cost-benefit analysis, but instead can defer to a congressionally recognized special value in the continued existence of an endangered species, see Endangered Species Act, 16 U.S.C. $\$ 1536$ (Supp. V 1975) (requiring all federal agencies to avoid jeopardizing existence of species on endangered list), or the preservation of parkland, see Citizens to Preserve Overton Park, Inc. v. Volpe, 401 U.S. 402 (1971) (interpreting statute to require construction of road so as to preserve park). The task of measurement often will be difficult, but agencies ought to grapple with the values at stake rather than arbitrarily discard an available mitigation measure. Furthermore, such analysis will expose the agency's reasoning to review and criticism. See pp. 608-10 infra.

57. Alternatives include suggestions of mass transit rather than highways, flood plain zoning rather than dam construction, and energy conservation rather than development of federal coal resources. Cf. Council Guidelines, 40 C.F.R. $\$ 1500.8(a)(4)$ (1977) (using similar definition). 
(2) requiring application of better pollution control technology;

(3) changing the location of the action within a region;

(4) repairing or restoring the affected environment;

(5) minimizing the adverse effects during the action through preservation and maintenance; and

(6) compensating for adverse effects by providing replacements or substitutes for the destroyed environment. ${ }^{58}$

Moreover, the amendments explicitly provide for inclusion of scientific observation in monitoring programs and for use of information derived from monitoring programs in future EISs. The monitoring programs should evaluate the predicted effects of mitigation measures and should therefore include collection of data about the impact of an action and the ameliorating effects of the mitigation measures. ${ }^{59}$

Monitoring programs should extend for periods sufficient to discover the effects of mitigation measures. ${ }^{60}$ An agency can change measures during the course of an action upon discovering that a mitigation measure is not producing the predicted results. Data from the monitoring programs should be published in a form that allows comparison of the hypothesized value of the measures with their observed value. ${ }^{61}$ Adoption of these amendments will give agencies guidance for making a reasoned choice on a public record from among suggested mitigation measures.

\section{B. Implications for Judicial Review}

In reviewing alleged violations of the practicable mitigation standard, courts will confront different situations than in current NEPA cases. Not only the informational adequacy of the EIS, but also agency action based upon the relevant information will be scrutinized. ${ }^{62}$

58. These amendments would replace Proposed Regulations, supra note 4, § 1508.19 .

59. Carpenter, supra note 22, at 50,019.

60. The current state of the art does not include neat calculations of the time necessary for observation of ecosystems. See id. at 50,017 (observation should continue for "a number of years, even decades"). Nonetheless, preparation of an EIS at least should be used to improve the state of the art.

61. Such a format will facilitate requisite scientific criticism. See Schindler, supra note 22.

62. Bardach and Pugliaresi, supra note 16, argue that judicial revicw of agency preparation of the EIS ought to be precluded because such review makes agencies so defensive that they prepare the EIS solely to satisfy courts rather than for use in agency decisions. By focusing judicial review not solely on preparation of the EIS, but also on its evaluation and use, the standards proposed in this Note decrease the possibility that a "defensive" agency can prepare a merely pro forma EIS. The EIS becomes important 
Yet, the focus on practicable mitigation measures rather than on the choice of alternative courses of action should make expanded review manageable. ${ }^{63}$

Ample legal authority exists for the more comprehensive judicial review of agency decisions that would take place under the amended standards proposed in this Note. ${ }^{04}$ By increasing the visibility of agency decisions and by providing more information to a reviewing court, the proposed amendments should facilitate the judicial function. The standards, moreover, would strengthen judicial review in two significant ways: procedural review would be more thorough, and sub. stantive review would produce greater agency compliance with the goals of NEPA.

\section{Procedural Review}

Under the amended regulations courts still would engage in traditional procedural review to ensure that an agency has considered all relevant factors in its EIS. ${ }^{\circ 5}$ Consideration and analysis of all appropriate mitigation measures would be even more important because

both in the initial decision among alternative courses of action and in subsequent mitigation decisions. Because an agency will be allowed to change or manipulate costbenefit calculations in its EIS only with great difficulty after preparation of the EIS is completed, agencies will have strong incentives to prepare the EIS carefully. Moreover, because the standards proposed in this Note will increase information available on the record, courts will be better able to evaluate the validity of each EIS as well as the decision based on it.

63. An agency first would choose from among national priorities through the selection of an alternative course of action. But courts then would require the agency to minimize the sacrifice of another national priority-the protection of the environment-through the use of all practicable mitigation measures, and compensate users of the environmental resource destroyed either through minimization of harm or through replacement of the resource.

64. The record of decision produced by an administrative agency, such as the record proposed in this Note, is certainly reviewable. Citizens to Preserve Overton Park, Inc. v. Volpe, 401 U.S. 402, 410 (1971); Association of Data Processing Serv. Organizations v. Camp, 397 U.S. 150, 157 (1970); Abbott Laboratories, Inc. v. Gardner, 387 U.S. 136, 140, 141 (1967); see County of Suffolk v. Secretary of Interior, 562 F.2d 1368, 1383, 1384 (2d Cir. 1977), cert. denied, 434 U.S. 1064 (1978) (review of similar record of decision used in oil and gas lease sale).

Under the proposed regulations the Council is to review all EISs that are found objectionable by another commenting agency. Proposed Regulations, supra note $4, \S 1504$. However, Council review of an EIS that another agency has found wanting will be limited to matters of national importance-primarily the selection of alternative courses of action. Id. $\$ \$ 1504.2, .3(\mathrm{e})(4)$. In reviewing such referrals, the Council will be limited to the remedies of publicity and persuasion. $I d$. $\$ 1504.3(\mathrm{e})$. Thus Council review of the EIS is an additional method of correction of the few environmentally unsound projects that rise to the level of national importance, rather than a mechanism that preempts review in the courts.

65. See note 10 supra (traditional procedural review limited to ensuring consideration of relevant information). 
the EIS is designed to provide the basis for selecting the measures. Courts also might have to require consideration of data developed in earlier monitoring programs if an agency fails to take that information into account in making later decisions. If a mitigation measure adopted on the record of decision is not implemented, or a monitoring program is not established and publicized, a court could order the necessary performance.

\section{Substantive Review}

A more problematic case for judicial review will arise when an agency fails to choose on its record of decision a mitigation measure suggested in the EIS. Some courts have held that review of the substance of agency decisions within the standards of NEPA is possible, but have refrained from such review. ${ }^{66}$ The scope of review under the Council's proposed regulations will be changed somewhat by the presence of a record of decision that is presumed to be reviewable. ${ }^{.7}$ Yet, the Council's proposed regulations fail to provide a standard of review for use by the courts.

Under the recommended amendments, in contrast, a court would enjoin further action if an agency failed to adopt a mitigation measure defined as practicable in the EIS. An agency could avoid adoption of such mitigation measures only if it could show that a change in the state of the art made another mitigation measure more desirable ${ }^{88}$ or that changed environmental conditions made the mitigation measure unnecessary. ${ }^{69}$ An agency, therefore, could justify a failure to adopt a mitigation measure by showing an objective change in the underlying data, but not by manipulating the costbenefit analysis already performed. The agency would be bound by its EIS $^{\text {to }}$ since courts would require the agency to use the EIS to design its action.

66. See Environmental Defense Fund, Inc. v. Corps of Eng'rs, 492 F.2d 1123 (5̈th Cir. 1974); Environmental Defense Fund, Inc. v. Corps of Eng'rs, 470 F.2d 289 (8th Cir. 1972), cert. denied, 412 U.S. 931 (1973).

67. See note 64 supra.

68. For instance, an agency could use a more advanced pollution control device, but it would not be free to use none when the EIS had suggested otherwise.

69. For instance, destruction of the fish in a river could make construction of a fish ladder around a dam unnecessary, or discovery of another population of an endangered species could make preservation of the population threatened by the agency action unnecessary.

70. The EIS is prepared first by a separate environmental office within most agencies. See Wichelman, supra note 16 , at $280-83$. Under this proposal the EIS would then be used by agency decisionmakers to design the agency action. This would be an improvement over the current system in which the EIS is frequently ignored by agency decisionmakers. See Bardach \& Pugliaresi, supra note 16 (EIS not used by agency decisionmakers). 


\section{Conclusion}

Full implementation of NEPA by agencies must progress through three phases: interpretation of NEPA's procedural message, formal compliance with its procedures, and integration of NEPA's policy into agency decisions. ${ }^{71}$ Most agencies have entered at least the formal compliance phase. The EIS has been the tool through which much of this progress has been achieved.

A change in the focus of Council guidance, agency implementation, and judicial review must take place in order to move agencies from formal compliance with NEPA to integration of its goals with primary agency policy decisions. Part of the change must come from employment of the EIS in the earliest stages of agency planning. The other source of change must be reliance on the EIS during implementation of the agency's activities. Information gathered in the EIS is valuable only if the agency uses it to design and control its actions.

71. Wichelman, supra note 16 , at 265-67. 